\title{
Protective Effects of Femented Soymilk Extract on High Glucose-Induced Oxidative Stress in Human Umbilical Vein Endothelial Cells
}

\author{
Nan Yi, Min-Jung Park, and Ji-Sook Han $^{\dagger}$ \\ Department of Food Science and Nutrition, Pusan National University, Busan 609-735, Korea
}

\begin{abstract}
We investigated whether the femented soymilk extract (FSE) has protective effects against high glucose-induced oxidative stress in human umbilical vein endothelial cells (HUVECs). FSE was prepared via fementation of soymilk with Bacillus subtilis followed by methanol extraction. To detemine the protective effect of FSE, oxidative stress was induced by exposing of HUVECs to the high glucose $(30 \mathrm{mM})$ for $48 \mathrm{hr}$. Exposure of HUVECs to high glucose for $48 \mathrm{hr}$ resulted in a significant $(p<0.05)$ decrease in cell viability, catalase, SOD and GSH-px activity and a significant $(\mathbf{p}<\mathbf{0 . 0 5})$ increase in intracellular ROS level and thiobarbituric acid reactive substances (TBARS) fomation in comparison to the cells treated with $5.5 \mathrm{mM}$ glucose. However, at concentration of 0.1 mg/mL, FSE treatment decreased intracellular ROS level and TBARS fomation, and increased cell viability and activities of antioxidant enzymes including catalase, SOD and GSH-px in high glucose pretreated HUVEC. These results suggest that FSE may be able to protect HUVECs from high glucose-induced oxidative stress, partially through the antioxidative defense systems.
\end{abstract}

Key words: fermented soymilk extract, HUVECs, high glucose, oxidative stress

\section{INTRODUCTION}

Free radicals and reactive oxygen species generated in cells are effectively scavenged by the antioxidant defense system which consists of antioxidant enzymes such as catalase, SOD, GSH-px, and GR. When the activity of the antioxidant defense system decreases or the ROS production increases an oxidative stress may occur (1). Recently, compelling evidence has been provided that onset and progression of diabetes and its complications are closely associated with oxidative stress (2,3). Hyperglycemia-induced oxidative stress is detrimental to endothelial cells and contributes to the vascular complications of diabetes (4-6). Prolonged hyperglycemia is the major factor in the etiology of atherogenic pathogenesis in diabetes, which causes $80 \%$ of total mortality in diabetic patients. Micro- and macrovascular complication of diabetes have complexity of pathogenesis involving dysfunction of and damage to vascular endothelial cells (7), which are susceptible to stimulatory factors such as increased glucose concentration, oxidative stress, and advanced glycation end products (8).

Soybean, the most important legume in the Asian diet, is rich in high-quality protein, including lysine and other essential amino acids (9). In addition to proteins, soy beans contain various nutritional and functional components such as isoflavones. The interest in the potential health effects of soybean and soy isoflavones is growing as epidemiological studies have associated a diet rich in isoflavones with a lower risk of certain diseases (10-12). Recently, soybean and soy protein have received much attention for their preventive effects on chronic disease (13-15). However, two of the main oligosaccharides in soybeans, raffinose and stachyose, are not nutritionally useful because these are fermented by microbes present in the gut, resulting in flatulence and discomfort. Fermentation is a chemical reaction that splits complex organic compounds into relatively simple substances. Fermentation of soymilk by mixed cultures of bifidobacteria and lactic acid bacteria has been shown to effectively decrease the content of the two nondigestable oligosaccharides. Interestingly, fermentation of legumes has been reported to improve their nutritional value by increasing protein digestibility, monosaccharide content, and vitamin B family biosynthesis, as well as decreasing non-nutritive factors (16). Soybean products fermented with Bacillus subtilis are widely consumed in Asia, including Chungkookjang and natto.

B. subtilis, which is safe for human consumption and which grows rapidly, making it easy to scale-up for mass culture, has been a good organism to develop as a probiotic diet adjunct. Kuo et al. (17) reported that Bacillus subtilis-fermented natto hydrolyzed daidzin and genistin 
to daidzein and genistein, respectively, in black soymilk. Soymilk, the water extract from ground soybeans, is a colloidal dispersion and most of the components present in the soybean are also present in soymilk. During fermentation, the active compounds in soymilk are exposed. Therefore, this study was designed to examine whether the soymilk fermented with Bacillus subtilis has protective effects against high glucose-induced oxidative stress in human umbilical vein endothelial cells (HUVECs).

\section{MATERIALS AND METHODS}

\section{Preparation of FSE}

Soymilk was purchased from Donghwa food, Inc. (Yangsan, Korea). Soymilk was fermented by Bacillus subtilis isolated from Chungkookjang for $6 \mathrm{hr}$ at $40^{\circ} \mathrm{C}$ under aerobic conditions. Non-fermented as well as the fermented soymilk was freeze-dried, powdered and extracted with ten volumes of $100 \%$ methanol for $12 \mathrm{hr}$ three times at room temperature. The filtration of the extracted solution and evaporation under reduced pressure yielded methanol extract. After the extract was thoroughly dried for complete removal of solvent, the dried extract was then stored in a deep freezer $\left(-80^{\circ} \mathrm{C}\right)$.

\section{Cell culture}

Human umbilical vein endothelial cells (HUVECs) and endothelial cell basal medium-2 (EBM-2) with endothelial cell growth medium-2 (EGM-2) bullet kit were purchased from Clonetics Inc. (San Diego, USA). Cells in passages $3 \sim 6$ were used. Cells were cultured in EGM-2 containing $2 \%$ fetal bovine serum (FBS; Gibco Inc., NT, USA) at $37^{\circ} \mathrm{C}$ in a humidified atmosphere containing $5 \% \mathrm{CO}_{2}$, according to the supplier's recommendation.

\section{Assay of neutral red cell viability}

Cell viability was assessed by measuring the uptake of the supravital dye neutral red (18). Cells $\left(4 \times 10^{4}\right.$ cells/well) were seeded in 24-well plate and pre-incubated with glucose $(5.5$ and $30 \mathrm{mM})$ in humidified atmosphere containing $5 \% \mathrm{CO}_{2}$ at $37^{\circ} \mathrm{C}$ for $48 \mathrm{hr}$. After $48 \mathrm{hr}$ of incubation, the cells were treated with various concentrations (0.1, 0.5 and $1.0 \mathrm{mg} / \mathrm{mL}$ of FSE) and further incubated for $20 \mathrm{hr}$. Thereafter, the medium was carefully removed from each well, and replaced with 0.5 $\mathrm{mL}$ of fresh medium containing $1.14 \mathrm{mmol} / \mathrm{L}$ neutral red. After $3 \mathrm{hr}$ of incubation, the medium was removed and the cells were washed twice with phosphate buffered saline (PBS, pH 7.4). The incorporated neutral red was released from the cells by incubation in the presence of $1 \mathrm{~mL}$ of cell lysis buffer $[50 \mathrm{mmol} / \mathrm{L}$ Tris- $\mathrm{HCl}(\mathrm{pH} 7.4)$,
$150 \mathrm{mmol} / \mathrm{L} \mathrm{NaCl}, 5 \mathrm{mmol} / \mathrm{L}$ dithiothreitol (DTT), and $1 \%$ Triton X-100] containing $1 \%$ acetic acid and 50\% ethanol at room temperature for $15 \mathrm{~min}$. To measure the dye taken up, the cell lysis products were centrifuged and the absorbance of supernatant was measured spectrophotometrically at $540 \mathrm{~nm}$.

\section{Assay of intracellular ROS levels}

Intracellular ROS levels were measured by the $2^{\prime}, 7^{\prime}$-dichlorofluorescein diacetate (DCF-DA) assay (19). DCF-DA can be deacetylated in cells, where it can react quantitatively with intracellular radicals to convert into its fluorescent product, DCF, which is retained within the cells. Therefore, DCF-DA was used to evaluate the generation of ROS in oxidative stress. Cells $\left(2 \times 10^{4}\right.$ cells/well) were seeded in a 96-well plate and pre-incubated with glucose $(5.5$ and $30 \mathrm{mM})$ in humidified atmosphere containing $5 \% \mathrm{CO}_{2}$ at $37^{\circ} \mathrm{C}$ for $48 \mathrm{hr}$. After $48 \mathrm{hr}$ of incubation, the cells were treated with various concentrations $(0.1,0.5$, and $1.0 \mathrm{mg} / \mathrm{mL})$ of FSE and further incubated for $20 \mathrm{hr}$. Thereafter, the medium was removed and the cells were washed twice with phosphate buffered saline (PBS, pH 7.4) and then were incubated with $5 \mu \mathrm{M}$ DCF-DA for $30 \mathrm{~min}$ at room temperature. Fluorescence was measured using a fluorescence plate reader.

\section{Assay of lipid peroxidation}

Lipid peroxidation was measured by thiobarbituric acid reactive substance (TBARS) production (20). Cells $\left(4 \times 10^{4}\right.$ cells/well $)$ were seeded in 24 -well plate and pre-incubated with glucose $(5.5$ and $30 \mathrm{mM})$ in humidified atmosphere containing $5 \% \mathrm{CO}_{2}$ at $37^{\circ} \mathrm{C}$ for $48 \mathrm{hr}$. After $48 \mathrm{hr}$ of incubation, the cells were treated with various concentrations $(0.1,0.5$, and $1.0 \mathrm{mg} / \mathrm{mL})$ of FSE and further incubated for $20 \mathrm{hr}$. $200 \mu \mathrm{L}$ of each medium supernatant was mixed with $400 \mu \mathrm{L}$ of TBARS solution then heated at $95^{\circ} \mathrm{C}$ for $20 \mathrm{~min}$. The absorbance at 532 $\mathrm{nm}$ was measured and TBARS concentrations were extrapolated from the 1,1,3,3-tetraethoxypropane serial dilution standard curve, TBARS values were then expressed as equivalent nmoles of malondialdehyde (MDA).

\section{Assay of nitric oxide (NO) level}

Cells $\left(2 \times 10^{4}\right.$ cells/well $)$ were seeded in 96-well plate and pre-incubated with glucose $(5.5$ and $30 \mathrm{mM})$ in humidified atmosphere containing $5 \% \mathrm{CO}_{2}$ at $37^{\circ} \mathrm{C}$ for 48 $\mathrm{hr}$. After $48 \mathrm{hr}$ of incubation, the cells were treated with various concentrations $(0.1,0.5$ and $1.0 \mathrm{mg} / \mathrm{mL})$ of FSE and further incubated for $20 \mathrm{hr}$. Thereafter, each $50 \mu \mathrm{L}$ of culture supernatant was mixed with an equal volume of Griess reagent [0.1\% N-(1-naphthyl)-ethylenediamine, $1 \%$ sulfanilamide in $5 \%$ phosphoric acid] and incubated 
at room temperature for $10 \mathrm{~min}$. The absorbance at 550 $\mathrm{nm}$ was measured in a microplate absorbance reader, and a series of known concentrations of sodium nitrite was used as a standard (21).

\section{Assay for antioxidant enzymes}

Cells $\left(1 \times 10^{6}\right.$ cells/dish $)$ in $10-\mathrm{mm}$ dishes were preincubated with glucose $(5.5 \mathrm{mM}, 30 \mathrm{mM})$ for $48 \mathrm{hr}$ then further incubated with or without the indicated concentrations of FSE for $20 \mathrm{hr}$. The medium was removed and the cells were washed twice with PBS. One milliliter of $50 \mathrm{mmol} / \mathrm{L}$ potassium phosphate buffer with 1 mmol/L EDTA ( $\mathrm{pH} 7.0)$ was added and the cells were scraped. Cell suspensions were sonicated three times for $5 \mathrm{sec}$ on ice each time then cell sonicates were centrifuged at $10,000 \times g$ for $20 \mathrm{~min}$ at $4^{\circ} \mathrm{C}$. Cell supernatants were used for measuring antioxidant enzyme activities. The protein concentration was measured by using the method of Bradford (22) with bovine serum albumin as the standard. SOD activity was determined by monitoring the auto-oxidation of pyrogallol (23). A unit of SOD activity was defined as the amount of enzyme that inhibited the rate of oxidation of pyrogallol. Catalase activity was measured according to the method of Aebi (24) by following the decreased absorbance of $\mathrm{H}_{2} \mathrm{O}_{2}$. The decrease of absorbance at $240 \mathrm{~nm}$ was measured for $2 \mathrm{~min}$. Standards containing $0,0.2,0.5,1$ and $2 \mathrm{mmol} / \mathrm{L}$ of $\mathrm{H}_{2} \mathrm{O}_{2}$ were used for the standard curve. GSH-px activity was measured by using the method of Lawrence and Burk (25). One unit of GSH-px was defined as the amount of enzyme that oxidizes $1 \mathrm{nmol}$ of NADPH per consumed per minute.

\section{Statistical analysis}

The data are represented as mean $\pm \mathrm{SD}$. The statistical analysis was performed with SAS program. The values were evaluated by one-way analysis of variance (ANOVA) followed by post-hoc Duncan's multiple range tests.

\section{RESULTS AND DISCUSSION}

\section{Cell viability}

Fig. 1 shows the effects of FSE and SE on the cell viability in HUVECs treated with high glucose of 30 $\mathrm{mM}$. Cell viability was examined by neutral red (NR) assay. When HUVECs were treated with $30 \mathrm{mM}$ glucose for $48 \mathrm{hr}$, there was a significant decrease in cell viability compared with the cells treated with $5.5 \mathrm{mM}$ glucose $(\mathrm{p}<0.05)$. However, the treatment with FSE at $0.5 \mathrm{mg} / \mathrm{mL}$ increased cell viability up to $78.71 \%$ in high glucose pretreated HUVECs and this showed higher cell viability than that of $55.60 \%$ in the cells treated same concen-

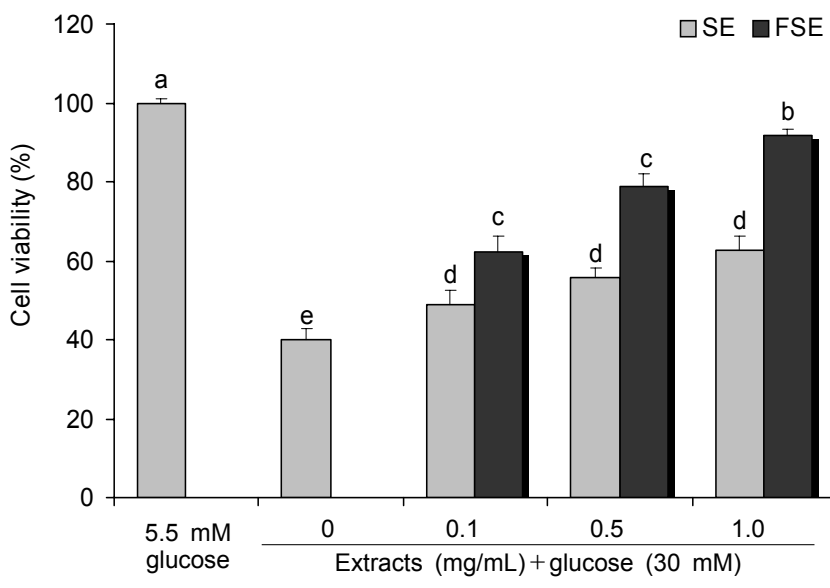

Fig. 1. Effects of FSE on cell viability in high glucose treated HUVECs. Cells in 24 well plates $\left(4 \times 10^{4}\right.$ cells/well $)$ were preincubated with $5.5 \mathrm{mM}$ normal glucose or $30 \mathrm{mM}$ high glucose for $48 \mathrm{hr}$, and then incubated with or without the indicated concentrations of soymilk extract and fermented soymilk extract $(0,0.1,0.5,1 \mathrm{mg} / \mathrm{mL})$ for $20 \mathrm{hr}$. Each value is expressed as mean $\pm \mathrm{SD}(\mathrm{n}=3)$. Values with different letters are significantly different at $\mathrm{p}<0.05$ as analysis by Duncan's multiple rang test. SE: soymilk extract, FSE: fermented soybean milk extract.

tration of SE $(p<0.05)$, suggesting the fermentation of SE with $B$. subtilis may be useful in high-glucose treated cells.

Fermentation consists of modifying food by microorganisms that grow and reproduce and consume part of the substrate and enrich it with the products of their metabolism. Soymilk contains beneficial components for human health, such as soy protein, peptides, and isoflavones. The fermentation of soymilk was suspected to result in various compositional and functional changes as the fermentation of soybeans produce a large variety of peptides and amino acid by different kinds of microorganism. The results suggest that the amount of compounds increasing cell viability was increased during fermentation of SE.

Damage to the cell surface or sensitive lysosomal membranes decreases the uptake and binding of NR, making it possible to differentiate between viable intact cells and dead/damage cells. The high glucose-induced decrease in cell viability indicated that high glucose concentration might have damaged the cell surface or lysosomal membranes of HUVECs. Treatment of HUVECs with FSE resulted in a dose-dependent increase of cell viability, suggesting a protective effect on the cell surface or lysosomal membranes of HUVECs.

\section{Intracellular ROS level}

As presented in Fig. 2, the generation of intracellular ROS in HUVECs increased significantly after treatment with $30 \mathrm{mM}$ glucose compared with $5.5 \mathrm{mM}$ glucose. 


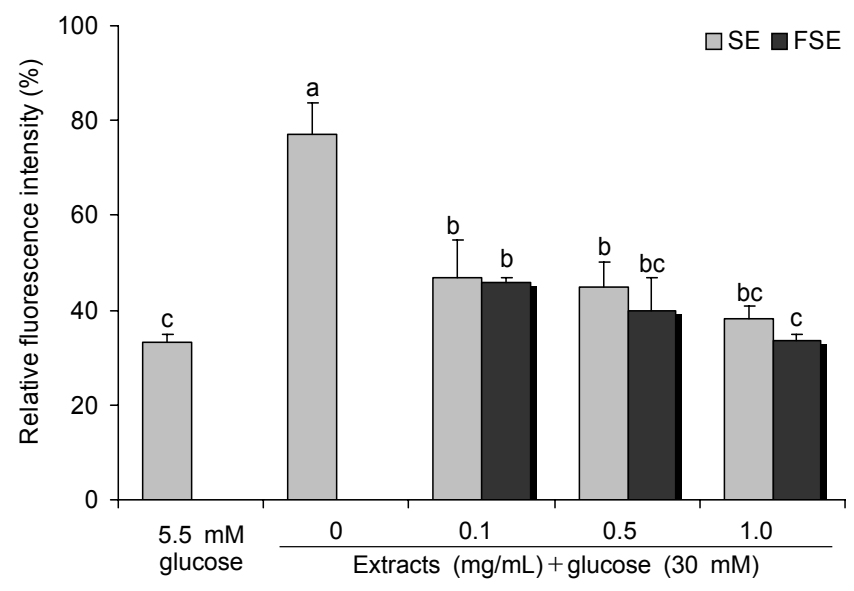

Fig. 2. Effects of FSE on intracellular ROS level in high glucose treated HUVECs. Abbreviations are the same as in Fig. 1. Each value is expressed as mean $\pm S D(n=3)$. Values with different letters are significantly different at $\mathrm{p}<0.05$ as analysis by Duncan's multiple rang test. SE: soymilk extract, FSE: fermented soybean milk extract.

When HUVECs were treated with $30 \mathrm{mM}$ glucose, intracellular ROS level increased significantly to $76.97 \%$. However, treatment with FSE decreased significantly the ROS level in the cells induced with $30 \mathrm{mM}$ glucose. Especially, treatment with $0.5 \mathrm{mg} / \mathrm{mL}$ of FSE resulted in a significant decrease in intracellular ROS level to $39.97 \%$ in comparison to the cells treated with the same concentration of SE (44.89\%). FES significantly decreased the elevated ROS level induced by high glucose, showing that fermentation of SE with $B$. subtilis has a greater inhibitory effect than SE on the ROS generation in high glucose treated the cells.

High ROS levels induce oxidative stress, which can result in a variety of biochemical and physiological lesions. Such cellular damage often impairs metabolic function, and leads to cell death (26). Our result showed that treatment of HUVECs with $30 \mathrm{mM}$ glucose significantly increased the intracellular ROS level. However, FSE inhibited the high glucose-induced ROS generation. Mitochondrial membrane was hyperpolarized under high glucose conditions and the production of ROS was increased (27). FSE greatly decreased intracellular ROS production. It seemed that FSE significantly decreased hyperglycemia-induced mitochondrial membrane hyperpolarization and the subsequent increased ROS production.

\section{Lipid peroxidation}

The effect of FSE on lipid peroxidation in high glucose-treated HUVECs was determined by measuring TBARS, a lipid peroxidation product (Fig. 3). When HUVECs were incubated with $5.5 \mathrm{mM}$ or $30 \mathrm{mM}$ glucose for $48 \mathrm{hr}$, TBARS in the $30 \mathrm{mM}$ glucose-treated

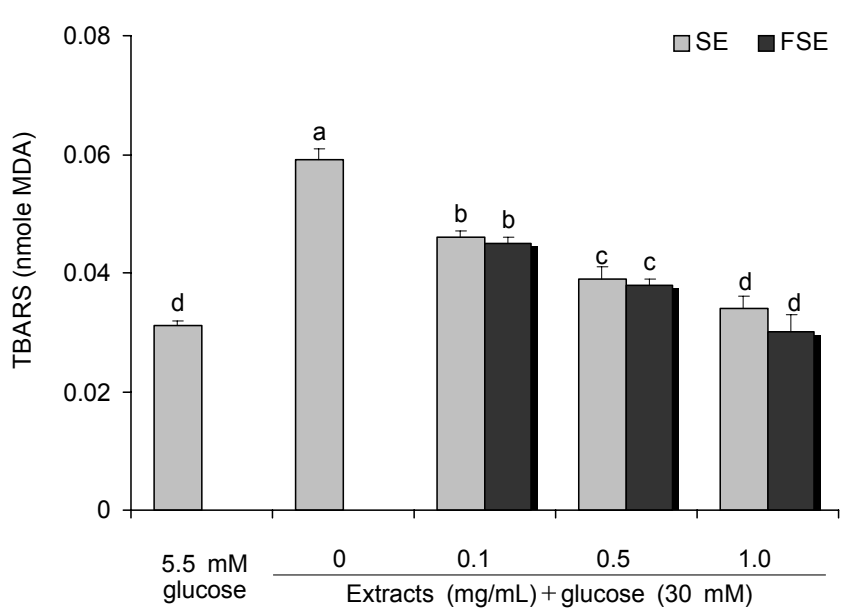

Fig. 3. Effects of FSE on TBARS generation in high glucose treated HUVECs. Abbreviations are the same as in Fig. 1. Each value is expressed as mean $\pm S D(n=3)$. Values with different letters are significantly different at $p<0.05$ as analysis by Duncan's multiple rang test. SE: soymilk extract, FSE: fermented soybean milk extract.

HUVECs was significantly increased $(\mathrm{p}<0.05)$ in comparison to the cells treated with $5.5 \mathrm{mM}$ glucose. Treatment of HUVECs with FSE of $0.5 \mathrm{mg} / \mathrm{mL}$ significantly suppressed TBARS formation in $30 \mathrm{mM}$ glucose pretreated cells, indicating protection against lipid peroxidation. FSE showed higher protective effects against lipid peroxidation than SE overall. Sevanian \& Hochstein suggest that lipid peroxidation is one of the forms of cell damage mediated by free radicals (28). In this study, high glucose $(30 \mathrm{mM})$-induced lipid peroxidation in HUVECs and FSE inhibited TBARS formation effectively.

One of the serious consequences of lipid peroxidation is the damage to biomembranes such as mitochondrial and plasma membranes. TBARS being produced by lipid peroxidation can cause cross-linking and polymerization of membrane components (29). This can alter intrinsic membrane properties such as deformability, ion transport, enzyme activity, and the aggregation state of cell surface determinants. Under extreme conditions, peroxidized membranes can lose their integrity (30). The protective action of FSE on TBARS formation, which may be attributed to its antiperoxidative effect, was demonstrated in this study.

\section{NO generation}

As shown in Fig. 4, the level of NO in HUVECs was significantly elevated by $30 \mathrm{mM}$ glucose treatment compared with $5 \mathrm{mM}$ glucose treatment. However, NO levels in FSE or SE treated cells were significantly decreased. The level of NO in HUVECs treated $30 \mathrm{mM}$ glucose was $0.304 \mu \mathrm{M}$, but treatment with $0.5 \mathrm{mg} / \mathrm{mL}$ of FSE 


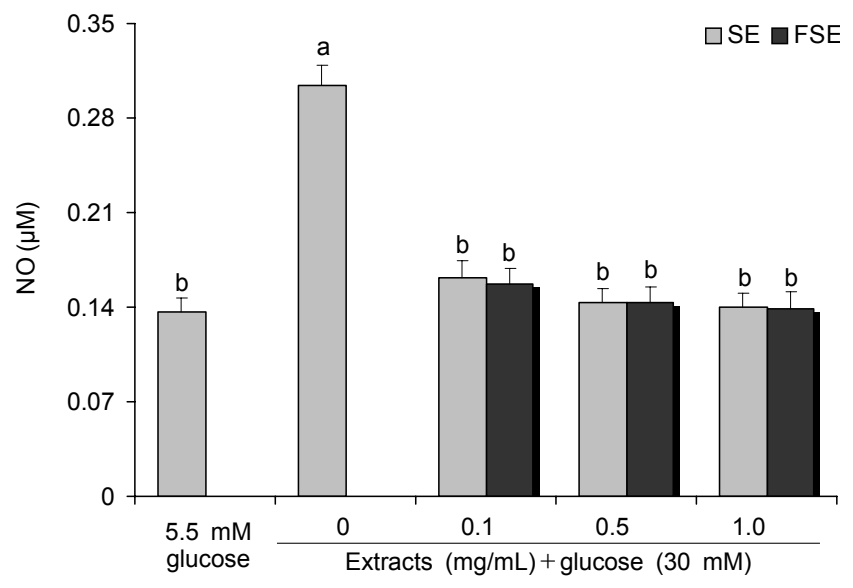

Fig. 4. Effects of FSE on NO level in high glucose treated HUVECs. Abbreviations are the same as in Fig. 1. Each value is expressed as mean $\pm \mathrm{SD}(\mathrm{n}=3)$. Values with different letters are significantly different at $\mathrm{p}<0.05$ as analysis by Duncan's multiple rang test. SE: soymilk extract, FSE: fermented soybean milk extract.

in the cells resulted in significant decrease in NO level to $0.143 \mu \mathrm{M}$. FSE scavenged NO produced by high glucose-induced oxidative stress.

Several researchers reported that suppression of NO production by plant extracts may be attributed to direct free radical scavenging. High glucose treatment leads to overproduction of NO and ROS. When NO is produced in large amounts, it reacts rapidly with superoxide anion to form peroxynitrite, a powerful oxidant, that damages many biological molecules, including DNA and proteins, and thus can lead to amplification of inflammation and tissue injury $(31,32)$. In addition, NO and superoxide anion induce highly reactive oxidative damage associated with diabetes (33). In this study, FSE inhibited intracellular ROS, NO and TBARS produced by high glucose induced oxidative stress, suggesting that FSE might confer protection against the oxidative stress induced by hyperglycemia.

\section{Antioxidant enzyme activities}

Cells are protected from activated oxygen species by endogenous antioxidant enzymes such as catalase, SOD and GSH-px. The effects of FSE on antioxidant enzyme activities in high glucose treated HUVECs are shown in Table 1. The $30 \mathrm{mM}$ glucose treatment decreased catalase activity compared with the cells treated with 5.5 $\mathrm{mM}$ glucose $(\mathrm{p}<0.05)$. FSE treatment increased the catalase activity in a dose dependent manner. Treatment with $30 \mathrm{mM}$ glucose for $48 \mathrm{hr}$ significantly decreased SOD activity of HUVECs $(p<0.05)$ compared with the cells treated with $5.5 \mathrm{mM}$ glucose. Treatment of HUVECs with FSE increased SOD activity of $30 \mathrm{mM}$ glucose pretreated cells. After the cells were treated with $0.5 \mathrm{mg} / \mathrm{mL}$ of FSE, SOD activity was significantly increased to $44.86 \mathrm{U} / \mathrm{mg}$ protein in comparison to high glucose treated cells $(35.14 \mathrm{U} / \mathrm{mg}, \mathrm{p}<0.05)$.

GSH-px activity in HUVECs treated with high glucose was significantly decreased in comparison to normal glucose treated cells $(p<0.05)$. Treatment with FSE in high glucose pretreated HUVECs resulted in an increase of GSH-px activity and this effect was concentration dependent. These antioxidant enzyme activities were higher by FSE treatment than SE on same concentration overall.

Our results showed a distinct decrease of the activities of antioxidant enzymes such as catalase, SOD, and GSH-px in HUVECs treated with high glucose compared with normal glucose level-treated cells. Treatment with FSE restored the antioxidant enzyme activities in high glucose-pretreated HUVECs. SOD, the endogenous scavenger, catalyses the dismutation of the highly reactive superoxide anion to $\mathrm{H}_{2} \mathrm{O}_{2}$ (34). The decreased activities of both catalase and GSH-px in the HUVECs treated with high glucose indicate a highly reduced capacity to scavenge $\mathrm{H}_{2} \mathrm{O}_{2}$ produced in the cells, with an increase in ROS and oxidative stress in response to high glucose treatment (35). The excess of superoxide anion

Table 1. Effects of FSE on antioxidant enzyme activities in high glucose treated HUVECs

\begin{tabular}{|c|c|c|c|c|}
\hline & & Catalase $(\mu \mathrm{mole} / \mathrm{mg}$ protein $/ \mathrm{min})$ & SOD (unit/mg protein) & GSH-px (unit/mg protein) \\
\hline \multicolumn{2}{|c|}{$\begin{array}{l}5.5 \mathrm{mM} \text { glucose } \\
30 \mathrm{mM} \text { glucose }\end{array}$} & $\begin{array}{l}1.79 \pm 0.04^{\mathrm{a}} \\
0.47 \pm 0.03^{\mathrm{d}}\end{array}$ & $\begin{array}{r}64.7 \pm 9.78^{\mathrm{a}} \\
35.14 \pm 2.71^{\mathrm{b}}\end{array}$ & $\begin{array}{l}4.94 \pm 0.08^{\mathrm{a}} \\
1.89 \pm 0.09^{\mathrm{d}}\end{array}$ \\
\hline $\begin{array}{l}\mathrm{SE}(\mathrm{mg} / \mathrm{mL})+ \\
30 \mathrm{mM} \text { glucose }\end{array}$ & $\begin{array}{l}0.1 \\
0.5 \\
1.0\end{array}$ & $\begin{array}{l}0.21 \pm 0.04^{\mathrm{e}} \\
0.62 \pm 0.05^{\mathrm{c}} \\
1.04 \pm 0.02^{\mathrm{b}}\end{array}$ & $\begin{array}{l}38.19 \pm 0.90^{\mathrm{b}} \\
42.11 \pm 8.14^{\mathrm{b}} \\
58.97 \pm 6.34^{\mathrm{a}}\end{array}$ & $\begin{array}{l}1.47 \pm 0.04^{\mathrm{d}} \\
1.78 \pm 0.06^{\mathrm{c}} \\
2.45 \pm 0.02^{\mathrm{b}}\end{array}$ \\
\hline $\begin{array}{l}\text { FSE }(\mathrm{mg} / \mathrm{mL})+ \\
30 \mathrm{mM} \text { glucose }\end{array}$ & $\begin{array}{l}0.1 \\
0.5 \\
1.0\end{array}$ & $\begin{array}{l}0.25 \pm 0.01^{\mathrm{e}} \\
0.79 \pm 0.07^{\mathrm{c}} \\
1.55 \pm 0.04^{\mathrm{b}}\end{array}$ & $\begin{array}{l}38.56 \pm 3.37^{\mathrm{b}} \\
44.86 \pm 7.37^{\mathrm{b}} \\
61.41 \pm 4.88^{\mathrm{a}}\end{array}$ & $\begin{array}{l}1.57 \pm 0.01^{\mathrm{d}} \\
2.04 \pm 0.07^{\mathrm{c}} \\
3.49 \pm 0.11^{\mathrm{b}}\end{array}$ \\
\hline
\end{tabular}

Abbreviations are the same as in Fig. 1. Each value is expressed as mean $\pm S D(n=3)$. Values with different letters in a column are significantly different at $\mathrm{p}<0.05$ as analysis by Duncan's multiple rang test. SE: soymilk extract, FSE: fermented soybean milk extract. 
radical, as a consequence of a reduction in the activity of SOD, might be responsible for the decrease in the activities of catalase in high glucose treated HUVECs. These elevations of antioxidant enzyme activities by FSE might support that it contains antioxidant compounds to help the attenuation of oxidative stress.

In conclusion, we demonstrated that FSE can protect HUVECs from high glucose-induced oxidative stress by increasing antioxidant enzymes activities, cell viability and decreasing intracellular ROS generation and lipid peroxidaion.

\section{ACKNOWLEDGEMENTS}

This research was financially supported by the Ministry of Education, Science Technology (MEST) and Korea Institute for Advancement of Technology (KIAT) through the Human Resource Training Project for Regional Innovation.

\section{REFERENCES}

1. Gulter RG, Packer LB, Eartum J, Mori A. 1995. Oxidative stress, antioxidants, aging and disease. In Oxidative stress and aging. Birkhauser Verlag, Basel, Switzerland. p 152-163.

2. Rosen P, Nawroth PP, King G, Moller W, Tritschler HJ, Packer L. 2001. The role of oxidative stress in the onset and progression of diabetes and its complications: a summary of a congress series sponsored by UNESCO-MCBN, the American Diabetes Association and the German Diabetes Society. Diabetes Metab Res Rev 17: 189-212.

3. Wiernsperger NF. 2003. Oxidative stress: the special case of diabetes. Biofactors 19: 11-18.

4. Diabetes Control and Complications Trial Research Group. 1993. The effect of intensive treatment of diabetes on the development and progression of long-term complications in insulin-dependent diabetes mellitus. $N$ Engl $J$ Med 329: 977-986.

5. Kinoshita JH. 1990. A thirty year journey in the polyol pathway. Exp Eye Res 50: 567-573.

6. Kuusisto JL, Mykkanen K, Pyorala, Laakso M. 1994. NIDDM and its metabolic control predict heart disease in elderly subjects. Diabetes 43: 960-967.

7. Stehouwer CAD, Schaper NC. 1996. The pathogenesis of vascular complications of diabetes mellitus: One voice or many? Eur J Clin Invest 26: 535-543.

8. Celermajer DS. 1997. Endothelial dysfunction: Does it matter? Is it reversible? J Am Coll Cardiol 30: 325-333.

9. Wang YC, Yu RC, Chou CC. 2006. Antioxidative activities of soymilk fermented with lactic acid bacteria and bifidobacteria. Food Microbiol 23: 128-135.

10. Anderson JW, Johnstone BM, Cook N. 1995. Meta-analysis of the effects of soy protein intake on serum lipids. $N$ Engl J Med 333: 276-282.

11. Potter SM. 1998. Soy protein and cardiovascular disease: the impact of bioactive components in soy. Nutr Rev 56: 231-235.

12. Hermansen K, Sondergaard M, Hoie L, Carstensen M,
Brock B. 2001. Beneficial effects of a soy-based dietary supplement on lipid levels and cardiovascular risk markers in type 2 diabetic subjects. Diabetes Care 24: 228-233.

13. Anderson JB, Anthony M, Messina M, Garner SC. 1999. Effects of phyto-estrogens on tissues. Nutr Res Rev 12: 75-116.

14. Bingham SA, Atkinson C, Liggins J, Bluck L, Coward A. 1998. Phyto-estrogens: where are we now? Br J Nutr 79: 393-406.

15. Setchell KDR, Cassidy A. 1999. Dietary isoflavones: biological effects and relevance to human health. J Nutr 129: 758S-767S

16. Rebeca FO, Juana F, Rosario M, Henryk Z, Mariusz KP, Halina K, Concepcion V. 2007. Fermentation as a bio process to obtain functional soybean flours. J Agric Food Chem 55: 8872-8979.

17. Kuo LC, Cheng WY, Wu RY, Huang CJ, Lee KT. 2006. Hydrolysis of black soybean isoflavone glycosides by Bacillus subtilis natto. Appl Microbiol Biotechnol 73: 314-320.

18. Fautz R, Husen B, Hechenberger C. 1991. Application of the neutral red assay to monolayer cultures of primary hepatocytes: rapid colorimetric viability determination for the unscheduled DNA synthesis test (UDS). Mutat Res 253: $173-179$.

19. Leloup C, Magnan C, Benani A, Bonnet E, Alquier T, Offer G, Carriere A, Periquet A, Fernandez Y, Ktorza A, Casteilla L, Penicaud L. 2006. Mitochondrial reactive oxygen species are required for hypothalamic glucose sensing. Diabetes 55: 2084-2090.

20. Fraga CG, Leibovita RM, Roeder RG. 1988. Lipid peroxidation measured as thiobarbituric-reactive substances in tissue slices: characterization and comparision with homogenates and microsomes. Free Radic Biol Med 4: 155-161.

21. D'Agostino P, Ferlazzo V, Milano S, La Rosa M, Di Bella G, Caruso R. 2001. Anti-inflammatory effects of chemically modified tetracyclines by the inhibition of nitric oxide and interleukin-12 synthesis in J774 cell line. Int Immunopharmacol 1: 1765-1776.

22. Bradford MM. 1976. A rapid and sensitive method for the quantification of microgram quantities of proteins utilizing the principle of protein-dye binding. Ann Biochem 72: $248-254$.

23. Marklund S, Marklund G. 1974. Involvement of the superoxide anion radical in antioxidant of pyrogallol and a convenient assay for superoxide dismutase. Eur J Biochem 47: $469-474$

24. Aebi H. 1984. Catalase in vitro. Methods Enzymol 105: 121-126.

25. Lawrence RA, Burk RF. 1976. Glutathione peroxidase activity in selenium-deficient rat liver. Biochem Biophys Res Commun 71: 952-958.

26. Finkel T, Holbrook NJ. 2000. Oxidants, oxidative stress and the biology of aging. Nature 408: 239-247.

27. Zheng Z, Chen H, Ke G, Fan Y, Zou H, Sun X, Gu Q, $\mathrm{Xu} \mathrm{X}$, Ho PC. 2009. Protective effect of perindopril on diabetic retinopathy is associated with decreased vascular endothelial growth factor-to pigment epithelium-derived factor ratio. Diabetes 58: 954-964.

28. Sevanian A, Hochstein P. 1985. Mechanism and consequence of lipid peroxidation in biological systems. Annu Rev Nutr 5: 365-390

29. Hochstein P, Jain SK. 1981. Association of lipid peroxidation and polymerization of membrane proteins with er- 
ythrocyte aging. Fed Proc 40: 183-188.

30. Pacifici RE, Davies KJ. 1991. Protein, lipid and DNA repair systems in oxidative stress: The free radical theory of aging revisited. Gerontology 37: 166-180.

31. Yen GC, Lai HH. 2002. Inhibitory effects of isoflavones on nitric oxide- or peroxynitrite-mediated DNA damage in RAW 264.7 cells. Food Chem Toxicol 40: 1433-1440.

32. Mizutani K, Ikeda K, Nishikata T, Yamori Y. 2000. Phytoestrogens attenuate oxidative DNA damage in vascular smooth muscle cells from stroke-prone spontaneously hypertensive rats. J Hypertens 18: 1833-1840.

33. Mandrup-Poulsen T, Helqvist S, Wogensen LD, Mølvig
J, Pociot F, Johannesen J, Nerup J. 1990. Cytokine and free radicals as effector molecules in the destruction of pancreatic beta cell. Curr Top Microbiol Immunol 164: 169-193.

34. Husain K, Somani SM. 1998. Interation of exercise training and chronic ethanol ingestion on testicular antioxidant system in rat. J Appl Toxicol 18: 421-429.

35. Alptekin N, Seckin S, Yelkenci T, Toker NK, Toker G, Uysal M. 1996. Lipid peroxides, glutathione, $\gamma$-glutamylcysteine synthetase and $\gamma$-gutamyltranspeptidase activities in several tissues of rats following water-immersion stress. Pharmacol Res 34: 167-169.

(Received January 21, 2010; Accepted February 12, 2010) 